\title{
Computer Models and Post-Bandemer Redistricting
}

\author{
Michelle H. Browdy
}

Since the Supreme Court first held political redistricting ${ }^{1}$ to be justiciable in Baker 2 . Carr, ${ }^{2}$ legal challenges to districting plans have increased dramatically. ${ }^{3}$ Because the Court's 1986 decision in Davis v. Bandemer ${ }^{4}$ held partisan gerrymandering ${ }^{6}$ to be justiciable for the first time, ${ }^{6}$ even more litigation will likely accompany redistricting following the 1990 cen-

1. States are divided into geographical districts from which representatives are elected either for the United States House of Representatives or for state legislative bodies. Political redistricting occurs when states redraw their political boundary lines after each decennial census. Since the benefits and detriments of automated redistricting apply equally to both congressional and state legislative redistricting, this Note will not distinguish between them. The Supreme Court, however, does treat challenges to the two types of districts differently, applying tighter standards of population equality to congressional districts than to state legislative districts. Compare Karcher v. Daggett, 462 U.S. 725 (1983) (invalidating plan for New Jersey's congressional districts with average deviation from perfect population equality of $0.1384 \%$ ) with Brown v. Thomson, 462 U.S. 835 (1983) (upholding plan for Wyoming state legislature with maximum population deviation of $89 \%$ ).

2. 369 U.S. 186 (1962). In Baker, the Court held that a challenge to the disparity of population size in districts of the Tennessee General Assembly was justiciable under the equal protection clause, UI.S. ConST, amend XIV, $\$ 1$. A previous challenge to the lack of population equality in districts in Illinois had been held nonjusticiable when it was brought under the guaranty clause, U.S. CoNST. art. IV, $\$ 4$ (guaranteeing republican form of government to each state). See Colegrove v. Green, 328 U.S. $549(1946)$.

3. E.g., Karcher v. Daggett, 462 U.S. 725 (1983); Brown v. Thomson, 462 U.S. 835 (1983); Galfney v. Gummings, 412 U.S. 735 (1973) (upholding plan for state legislative districts with small deviations from population equality); Kirkpatrick v. Preisler, 394 U.S. 526, 530-31 (1969) (requiring that "State make a good-faith effort to achieve precise mathematical equality" of population in redistricting); Wesburry v. Sanders, 376 U.S. 1 (1964) (holding that populations in congressional districts must be as equal as practicable); Reynolds v. Sims, 377 U.S. 533 (1964) (enunciating "one man, one vote" standard in case regarding redistricting of state legislatures).

4. 478 U.S. 109 (1986) (plurality opinion).

5. "Gerrymandering" is "the process of dividing a state ... with such a geographical arrangement as to accomplish an ulterior or unlawful purpose, as, for instance, to secure a majority for a given political party in districts where the result would be otherwise if they were divided according to obvious natural lines." Black's Law Dictionary 618 (5th ed. 1979).

6. The Bandkmer case involved the 1981 redistricting of the Indiana state legislature. Indiana Democrats challenged the state redistricting plan enacted while Republicans controlled the Indiana House, Senate, and Governorship. In resolving the case, the Supreme Court held for the first time that "political gerrymandering cases are properly justiciable under the Equal Protection Clause." 478 U.S, at 143 (plurality opinion). But the Court went on to find that the evidence did not support the Dernocrats' claim that unconstitutional gerrymandering had occurred. $I d$. 
sus. ${ }^{7}$ Indeed, some commentators expect that every redistricting plan created after 1990 will face a court challenge. ${ }^{8}$

The fact that redistricting cases have tended to proliferate over time rather than to disappear suggests problems in the Court's adjudication of political redistricting cases. ${ }^{9}$ Additionally, the fact that redistricting plans are challenged continually suggests either dissatisfaction with the results of the current method of redistricting, or displeasure with the process of redistricting itself, irrespective of judicial problems. Based on recent condemnations of political redistricting, ${ }^{10}$ this Note proposes a reexamination of the suggestion, first discussed in the 1960's, ${ }^{11}$ that automated computer models ${ }^{12}$ be developed for use in redistricting. ${ }^{13}$

Most previous articles on automated redistricting have proposed computer models without explaining their unique political and legal significance. ${ }^{14}$ This Note hopes to fill a gap in the literature by demonstrating

7. See Brace \& Katosh, Redistricting Lawsuits Will Be A New' Growth Industry, Wall St. J., Aug. 29, § 1986, § 1, at 16, col. 3; see also Comment, Politics and Purpose: Hide ond Set w the Gerrynandering Thicket After Davis v. Bandemer, 136 U. PA. L. REv. 183, 186 (1987) ("inability of the [Republican and Democratic] parties to agree on the decision's ramifications foreshadows a litigious future").

8. Schmidt, New Age of Gerrymandering: Political Magic by Computer?, N.Y. Times, Jan. 10, 1989 , at A1, col. 5, A14, col. 3 ("'rule of thumb this time around is that every reapportionment plan will probably end up in some courtroom" " (quoting Jeffrey Wice, counsel for Democratic State Legislative Leaders Association)); High-Tech Vote Grabbing, Wall St. J., May 12, 1989, at A14, col. 1.

9. Cf. Elliott, INS v. Chadha: The Administrative Constitution, the Constitution, and the Legislative Veto, 1983 SUP. CT. REv. 125, 149 (footnote omitted):

If the principles of law declared in an opinion are recognized as dispositive, the Court's statement of the law will stand, literally unchallenged. On the other hand, if people continue to litigate, and lawyers and courts continue to have doubts about how these cases should be resolved, the Supreme Court is eventually moved to reexamine its previous statement of the law.

10. See infra notes $22-27$ and accompanying text. The possibility that these condemnations may not be well-founded does not refute the need for a change in the redistricting process. People's perceptions of problems in the political arena can be important whether or not these "problems" are real, and automated redistricting can counter both real and perceived problems in the current state of political redistricting. Cf. Elliott, The Future of Toxic Torts: Of Chemophobia, Risk as a Compensable Injury and Hybrid Compensation Systems, 25 Hous. L. Rev. 781, 793 (1988) ("in politics, appearances are reality"); Note, Choosing Representatives by Lottery Voting, 93 YALE L.J. 1283, 1308 n.132 (1984) (authored by Akhil Amar) (risk of appearance of manipulation in lottery voting is as significant as risk of actual manipulation).

11. See, e.g., Nagel, Simplified Bipartisan Computer Redistricting, 17 STAN. L. REv. 863 (1965) (describing computer program implementing redistricting algorithm); Weaver \& Hess, A Proredure for Nonpartisan Districting: Dex'elopment of Computer Techniques, 73 YaLE L.J. 288 (1963) (describing computer program implementing redistricting algorithm based on mathematical techniques of operations research).

12. For an explanation of automated computer models, see infra Section II.

13. Despite the dearth of articles written in favor of automated redistricting since the 1970 's, most scholarship on political redistricting still acknowledges, either explicitly or implicitly, such a possible role for computers in redistricting. See, e.g., Grofman, Criteria for Districting: A Social Science Perspective, 33 UCLA L. Rev. 77, 124-25 (1985); Schuck, The Thickest Thicket: Partisan Gernmandering and Judicial Regulation of Politics, 87 Colum. L. REv. 1325, 1352 n.110 (1987).

14. See, e.g., Nagel, supra note 11; Torricelli \& Porter, Towards the 1980 Census: The Reraportionment of New Jersey's Congressional Districts, 7 RuTGers J. Computers TECH. \& L. 135, 148-56 (1979) (proposing use of Apportionment Commission and computer techniques to redistrict New Jersey fairly after 1980 census); Weaver \& Hess, supra note 11. Torricelli and Porter do point out briefly that "[t]he proper use of computers can guarantee . . . a fair and effective vote by drawing the most compact and contiguous districts possible." Torricelli \& Porter, supra, at 141. 
how automated redistricting offers a unique opportunity to make the redistricting process reviewable by the voting public and the courts. This reviewability should make it possible to require redistricting to meet manageable, meaningful judicial standards. ${ }^{15}$ Computer models might also elevate the legislative redistricting debate from a battle over line drawing to a discussion of representational goals. The potential for review, and the traits which flow from that, make an automated solution, while no panacea, a significant improvement over the current state of redistricting.

Section I of the Note describes some of the characteristics of the political redistricting problem, including current dissatisfaction and proposed alternatives. Section II outlines the type of computer model envisioned by the term "automated redistricting." Section III discusses why computerized redistricting should not only meet the standards elucidated by the Supreme Court in previous case law, but also provide the Court with a means of developing meaningful, judicially manageable standards for determining unconstitutional gerrymanders. Section IV argues that the process-oriented focus inherent in automated redistricting may create an intent/effect dichotomy in the determination of gerrymanders, and Section $\mathrm{V}$ describes past successful experiences with the use of mathematical methods in voting problems.

\section{Political Redistricting: Problems and Proposals}

\section{A. Problems: The Redistricting Process}

Since Reynolds $v$. Sims ${ }^{16}$ and its progeny clarified the "one person, one vote" standard for political redistricting, states have been forced to redraw congressional boundary lines after each decennial census. ${ }^{17}$ State legislatures are responsible for political redistricting, and legislators now have the opportunity to redesign boundary lines for their own political interests every ten years. ${ }^{18}$ It is not unreasonable to presume that many of the dis-

15. One of the most valuable features of the process-oriented approach to redistricting afforded by an automated procedure is its capacity to provide meaningful standards for judicial analysis. See infra notes $41,71-73$ and accompanying text.

In contrast, current non-process-oriented judicial analyses of redistricting plans often provide standards which are not manageable. See, e.g., Davis v. Bandemer, 478 U.S. 109, 162 (1986) (Powell, J., concurring in part and dissenting in part) ("The plurality . . . fails to enunciate standards by which to determine whether a legislature has enacted an unconstitutional gerrymander.").

Alternatively, present judicially manageable redistricting standards are often not meaningful. See Gentrally Note, Rrapportionment: A Call for a Consistent Quantitatize Standard, 70 Iowa L. REv. $663,680-84$ (1985) (claiming that Court's application of different quantitative standards to state and congressional districts lacks constitutional or practical justification). Or else these manageable standards only appear to be meaningful. See infra text accompanying notes 59-62; see also R. voN Jhrring, The Struggle for LAW xiv-xvi (J. Lalor trans. 1879) (arguing that "back door" approach to resolution of lawsuits is contemptible).

16. 377 U.S. 533 (1964).

17. Sir Council of State Governments, Reapportionment in the 1970s: The Problems of Complance 10 (1971).

18. Set, e.g., Fein, Stain on the Electoral Process, Wash. Times, Sept. 5, 1989, at C1, col. 1 
trict lines are drawn for the benefit of politicians, rather than for the constituents they represent. ${ }^{19}$ And while the results of redistricting may be held up to the scrutiny of the courts, ${ }^{20}$ politicians have not been held accountable thus far for the process of redistricting. ${ }^{21}$

Many critics have found fault with both gerrymandering and the adjudication of redistricting cases. While the "anti-democratic practice of gerrymandering"22 has been blamed for distorting the results of elections ${ }^{23}$

("Through the employment of sophisticated computers, software and polling data, state legislators cleverly draw congressional boundaries around voter residences to accomplish re-election aspirations or party entrenchment."). For specific examples of the redistricting procedures undertaken by legislators, see Fund, Beware the Gerrynander, My Son, Nat'L Rev., Apr. 7, 1989, at 34 (describing steps leading to Phil Burton's well-known gerrymander of California's redistricting plan):

Through many warm nights that summer of ' 81 , Burton held court at a back-room table in

Frank Fat's Chinese restaurant in Sacramento, a two block walk from the state capitol build-

ing. Proud of his mastery of political demographics, Burton brazenly held late night sessions to bargain over the shape of California's future congressional districts. . . .

When Burton finally unveiled his computer-drawn magic-what he called his 'contribution to modern art'-politicians were struck dumb by his genius. . . . One district, drawn specifically for Burton's ally Howard Berman, was an incredible 385-sided figure that meandered through most of the San Fernando Valley.

.. Political scientist Bruce Cain has shown that Phil Burton's sessions at Frank Fat's netted the Democrats at least five extra House seats.

Id.; Madigan, The Next Battle Lines are Beginning to Forn, Chicago Tribune, Mar. 19, 1989, §4, at 1, col. 1, 7, col. 1:

[Michael] Madigan, now speaker of the Illinois House, recalled that the [1980 Illinois redistrictingl effort was a court battle of computers, with his computer eventually winning out because he was able to constantly jiggle proposed congressional lines based on fresh, complete information.

....

It was a genuine masterwork of redistricting.

One district alone, the 9th, snakes all the way up the lakefront into Evanston, over into

Morton Grove, then farther north a little bit-a fishhook filled with liberal Democrats proba-

bly guaranteeing the re-election of Democrat Sidney Yates until fate intervenes.

19. See Fund, supra note 18, at 35 (quoting "Screw the people!" as Assembly Speaker's response to complaint about California Democrats' passage of redistricting plan modified only slightly from previous plan rejected soundly by voter referendum); see also Review and Outlook: Caging the Gerrymander, Wall St. J., Apr. 11, 1988, at 26, col. 1 [hereinafter Caging the Gerrymander] (describing gerrymandered districts).

20. See supra notes 1-3 and accompanying text.

21. Cf. Balz, Redistricting Transforned by Computers: Technology Will Add Options-and Complications - to Decennial Event, Wash. Post, June 12,1989, at A17 ("Not so long ago, a grease pencil, a hand-held calculator and the right political instincts were about all anyone needed in the decennial battle of redrawing America's political districts."). But see Davis v. Bandemer, 478 U.S. 109, 173 (1986) (Powell, J., concurring in part and dissenting in part) (finding that relevant factors in adjudicating gerrymanders "include the nature of the legislative procedures by which the apportionment law was adopted and legislative history reflecting contemporaneous legislative goals"); see also Comment, supra note 7, at $221 \mathrm{n.221}$ and accompanying text (citing flaw of legislative procedure in Bandemer redistricting case, and Justice Powell's notice of it). However, judicial regulation of the legislative process used to adopt a redistricting plan is not the same as regulation of the process of line drawing itself. Legislative approval of a redistricting plan may occur well after the lines of the plan have been carefully gerrymandered.

22. Caging the Gerrymander, supra note 19 , at 26 , col. 1 .

23. Id. (complaining that "[i]n 1984, Republicans won $50.5 \%$ of [California's] U.S. House vote, yet Democrats won $60 \%$ of the seats"). Although a party's percentage of votes is not likely to be the same as the percentage of seats in a "first past the post" system, where the candidate winning the most votes in a district wins the seat for the entire district, see Tufte, The Relationship Betureen Seats and Votes in Two-Parly Systems, 67 AM. PoL. Scr. Rev. 540 (1973), one would expect that "a party that wins a majority of votes . . . [would win] an even larger majority of seats." Id. at 540; see also 
and for encouraging voter apathy, ${ }^{24}$ the Supreme Court has been charged with encouraging gerrymandering by its choice of criteria in deciding redistricting cases. For example, the Court's requirement of strict population equality across districts has been credited with giving legislators a free hand in drawing odd boundaries and an opportunity to justify gerrymandering. ${ }^{25}$ Gerrymandering has been associated with keeping discrete and insular groups from gaining representation in legislatures. ${ }^{26}$ And after more than twenty-five years of deciding redistricting cases, the Court is still criticized, even by its own members, for failing to provide judicially manageable standards for determining unconstitutional gerrymanders. ${ }^{27}$

\section{B. Proposals}

A range of approaches to the problem of gerrymandering and the adjudication of redistricting cases has been proposed. Several commentators have urged that the Court simply hold gerrymandering, or at least partisan gerrymandering, nonjusticiable. ${ }^{28}$ This view apparently rests on the premise that potential abuses by legislators are preferable to the likely untoward results of judicial intervention in the redistricting process. This proposal, however, offers no solution to those disenfranchised by present abuses in redistricting; eliminating judicial intervention seems particularly risky in a system in which legislators can approve redistricting plans in the face of overwhelming voter disapproval. ${ }^{28}$

Others have proposed improving redistricting by focusing on the political process used in line drawing, suggesting a move to nonpartisan or bipartisan redistricting committees. ${ }^{30}$ While these proposals address the

Grofman, For Single-Member Districts Random Is Not Equal, in REPRESENTATION AND REDISTRICTING Issues 55, 55 (1982) (random districting will not equate percentage of seats with percentage of votes).

24. Caging the Gerrymander, supra note 19, at 26, col. 2 ("Voters respond to the lack of competitive House elections by simply not voting in them. . . Far from avoiding their civic duty, many voters have concluded that incumbent protections give House Members de facto lifetime tenure."); see also Rosenbaum, It's a House of the Same Representatives, N.Y. Times, Sept. 25, 1988, at E1, col. 1, E4, col. 4 (citing incumbent re-election rate as high as $98 \%$ in 1986 and noting rate has been characterized as unhealthy). Despite public perceptions of problems in the incumbent re-election rate, the Supreme Court has held that some incumbent protection is not an unconstitutional goal for political redistricting. See Karcher v. Daggett, 462 U.S. 725, 740 (1983).

25. See Schuck, supra note 13, at 1328 \& n.22. Requiring population equality in districts may well add to opportunities to gerrymand because it is an incomplete standard. $C f$. Davis v. Bandemer, 478 U.S. at 168 (Powell, J., concurring in part and dissenting in part) ("exclusive or primary reliance on 'one person, one vote' can betray the constitutional promise of fair and effective representation by cnabling a legislature to engage intentionally in clearly discriminatory gerrymandering").

26. See Note, supra note 10, at 1290-91.

27. See Davis v. Bandemer, 478 U.S. 109, 162 (1986) (Powell, J., concurring in part and dissenting in part).

28. E.g., A. Bickel, The Least Dangerous Branch 193-97 (2d ed. 1986) (expressing concern that judicial intervention will lead to legitimation of gerrymandering); Schuck, supra note 13, at $1330,1336-61$ (suggesting dangers of partisan gerrymandering are overrated, and proposing that judicial alternatives are "unacceptable in practice, unworkable in principle, or both").

29. Sep supra note 19.

30. See B. Cain, The Reapportionment Puzzle 181-91 (1984); Adams, A Model State Reap- 
problem of deliberate manipulation of redistricting by political parties, they offer no real guidance to the committees on how to formulate acceptable plans. Since no plan can be completely neutral, ${ }^{31}$ it is necessary to provide additional standards for the nonpartisan or bipartisan committees to follow; the proposal on its own is incomplete. Another solution would resolve redistricting cases by requiring full disclosure of subjective intent on the part of legislators or redistricting committees; however, this requirement has been viewed as totally impracticable. ${ }^{\mathbf{3 2}}$

One commentator recently suggested that "the Court must focus more on the objective standards of political gerrymandering, such as the compactness concept advocated by Justice Powell." ${ }^{\prime 33}$ If the current state of redistricting is viewed as unacceptable then the development of objective standards for redistricting is an important goal. However, mere advocacy of the use of objective standards accomplishes nothing in the abstract. ${ }^{34}$ What is needed is a proposed set of objective standards, or at least a mechanism which ensures the development, implementation, and review of a workable set of standards.

\section{Automated Redistricting}

In the past, "criteria of fair representation" have been offered as a means of determining fair redistricting plans. ${ }^{36}$ But much as principles of

portionment Process, 14 HARv. J. ON Legis. 825 (1977). But see Grofman, supra note 13, at 124 (calling Adams' proposal "naive and misguided").

31. See Dixon, The Court, the People, and "One Man, One Vote", in Reapportionment in THE 1970s 7, 20 (N. Polsby ed. 1971) ("An astute member of an apportionment commission phrased the matter this way a few years ago: 'Every plan has a political effect, even one drawn by a seventh grade civics class whose parents are all nonpartisans and who have only the United States census data to work with." " (citation omitted)).

32. See Comment, supra note 7 , at $222-28$ (explaining "why an attempt to analyze the subjective motivations of legislators is fraught with problems of proof").

33. Id. at 233. Compactness is a measure used to distinguish between, for example, districts tightly packed around a central point-implying some degree of closeness between a representative and his constituents-and thin districts which snake through a state. See, e.g., Hofeller \& Grofman, Comparing the Compactness of Califormia Congressional Districts Under Three Different Plans: 1980,1982 , and 1984 (unpublished manuscript, 1987) (applying different measures of compactness to districts in order to compare redistricting plans). Lack of compactness is often offered as evidence of unconstitutional gerrymandering, based on the notion that long, snaky districts are more likely to result when unfair gerrymanders occur. See Davis v. Bandemer, 478 U.S. 109, 167 (1986) (Powell, $J$., concurring in part and dissenting in part) ("districts should be compact and cover contiguous territory, precisely because the alternative, '[i]ndiscriminate districting,' would be 'an open invitation to partisan gerrymandering' " (citing Reynolds v. Sims, 377 U.S. 533, 578-79 (1964))). But see Lowenstein \& Steinberg, The Quest for Legislative Districting in the Public Interest: Elusive or Illusory?, 33 UCLA L. Rev. 1, 22-23 (1985) (citation omitted):

Is there any virtue in compactness as such, other than as a prophylactic? Precious little, under modern conditions. Given modern methods of transportation and communication, the size or shape of a district has little effect on the ability of the legislator to represent his or her constituents .... Most of the more sophisticated writers on districting have recognized that the presence or absence of compact districts does not assure either the presence or absence of ... gerrymandering.

34. Cf. Comment, supra note 7, at 233-37 (proposing development of objective standards to improve redistricting adjudication, but offering no practical advice for implementation).

35. For example, one commentator describes 16 points as "criteria of fair representation" of 
flight cannot help people fly without a flying machine, criteria of fair representation cannot improve redistricting until there is a way to use the criteria affirmatively in drawing plans. This Note contends that improvements in computer technology offer a new opportunity to use the computer to "implement" the criteria of fair representation in redistricting. Automated redistricting allows methodical redistricting using the criteria of fair representation. The nature of computing also means that the process used in automated redistricting becomes reviewable, since the computer program used to create the plan can be made available to reviewers. ${ }^{36}$ Once the redistricting process becomes both methodical and reviewable, it will be possible to develop meaningful, objective standards for legislative and judicial use in redistricting. The computer is not a magical instrument which will automatically generate "correct results" in the redistricting process. However, by virtue of the explicitness required in computer programming, the computer can be used as a tool to make previously articulated theories of representation practicable.

The use of automated computer models in redistricting implies an active role for computers. That is, given a redistricting algorithm created for the legislature, the computer would actually draw the lines which delineate districts. ${ }^{37}$ In contrast, the present role of computers in redistricting is

which 13 directly affect redistricting:

1. Representation must be equal for each citizen [one person, one vote]. . . 2. The boundaries dividing the electoral districts must coincide with local political boundaries as much as possible. 3. Electoral districts must be compact and contiguous. . . . 4. The boundaries . . . should be drawn in such a way as to provide representation for political minorities . . . [and for 5.] ethnic and racial minorities . . . 6. The electoral system should not be biased in favor of any political party . . . [or in favor of any 7.] racial or ethnic group . . . 8. The electoral system should have a wide range of responsiveness to changes in the electorate's party preferences. . . [9. T]he rate at which a party wins seats per unit gain in the percentage of its vote should be constant . . . 10. There should be proportionality between the share of the seats won by any particular ethnic or racial group and its vote share. . . 11. The system should be competitive . . . 12. Each citizen should have equal power to affect the outcome of elections... [and 13. e]ach citizen's vote should be 'used' as much as possible toward the election of a candidate and the 'wasted' vote should be minimized . . . .

Lijphart, Comparative Perspectives on Fair Represenlation: The Plurality-Majority Rule, Geographical Districting, and Alternative Electoral Arrangements, in REPRESENTATION AND REDISTRICTINo IsSUES, supra note 23, at 143, 145-46 (citation omitted). For other compilations of potential criteria, see Lowenstein \& Steinberg, supra note 33, at 11, and Grofman, supra note 13, at 174.

Justice Powell, too, cites equality of population, compactness, contiguity, and adherence to political boundaries as desirable neutral criteria for judging redistricting plans. Davis v. Bandemer, 478 U.S. 109, 167-68 (1986) (Powell, J., concurring in part and dissenting in part).

36. Previously, only the resulting map and perhaps the legislative process used to approve the map would be available for judicial review. With automation, then, rather than having to glean the subjective intention of legislators by analyzing redistricting maps, see Comment, supra note 7 , at $187-88,222-37$, the Court will be able to analyze the objective "intent" of the redistricting procedure as preserved in the record of the computer program.

37. For examples of active redistricting model proposals, see J. WEAver, FaIR AND EQual DisTRICTS: A How-To-Do-It MANUAL ON CoMPUTER USE (1970), Nagel, supra note 11, and Weaver \& Hess, supra note 11. See also Brownstein, Spreading the Gain, 21 Nat'L J. 792, 794 (1989) (describing modified active role for computers: individuals draw lines but subject to strict algorithmic constraints); Note, Simulated Annealing: An Improved Computer Model for Political Redistricting, 8 YALE L. \& POL'Y REv. (forthcoming 1990) (explaining my proposal for new algorithm for redistricting). 
a passive one, in which people draw lines and use computers only to keep track of the population characteristics of districts. ${ }^{38}$ By shifting from a passive to an active use of computers, review of the redistricting process becomes manageable. ${ }^{3 \theta}$ Redistricting is achieved by programming the computer with a relatively small amount of information. The programmer must tell the computer how to redistrict, and this preprogrammed process becomes reviewable. ${ }^{40}$ With the steps describing the process for redistricting saved in a computer program and available for public scrutiny and judicial review, objective standards for reviewing redistricting plans can be developed. ${ }^{41}$

Additionally, ideal "automated redistricting models" should produce only a single plan of district boundary lines to be implemented in a state. While it is possible that different states will develop radically different computer programs for redistricting, ${ }^{42}$ a completely automated redistricting model is categorically distinguishable from other active uses of computers in political redistricting, such as those methods which produce several plans from which politicians can choose. ${ }^{43}$ Producing a single plan imposes a high standard of disclosure and accountability. ${ }^{44}$

Automated redistricting might be challenged because of the difficulty of

38. See, e.g., Goddard, Gerrymandering by Computer, Christian Sci. Monitor, Oct. 16, 1989, at 19 ("computer programs will allow legislators to fully manipulate election-district boundaries, getting instant statistics on the voting behavior and racial composition of the people in the redrawn districts"); Fein, supra note 18; Balz, supra note 21 (describing how redistricter uses computer mouse and "electronic lasso" to select districts that computer then analyzes).

This type of passive computer use, along with its potential abuses, is particularly significant, as computer use in the post- 1990 redistricting is expected to be extensive. See, e.g., Barnes, Drawing the Lines, 21 Nar'L J. 787 (1989); Barnes, Sharing the Pain, 21 NaT'L J. 795 (1989).

39. In contrast, passive computer use has no bearing on the subject of review in a gerrymandering case. Where computers are used passively, courts are still left to review hand-drawn lines, and legislators still face the difficult task of explaining how the lines were drawn.

40. For an explanation of how automating the redistricting process turns redistricting goals into computer terms, see sources cited supra note 37.

41. A range of objective standards reflecting the criteria of representation, supra note 35 , might be created by the courts, Congress, or the states. Questions including the following might be considered when developing such standards: Can political data beyond that provided by the census be used? Can racial data be employed? Must an objective of compactness be included? Contiguity? Can any standard be used? Can local political or racial groups be aggregated before the redistricting takes place? Thus automating redistricting provides a means of using objective criteria as desired by Justice Powell. See supra notes $33 \& 35$. Standards might be created as per se rules requiring, for example, the use of a compactness criterion. Or standards might be used to shift the burden of proof. For example, preliminary aggregation of political groups might be used as prima facie evidence of unconstitutional partisan gerrymandering, shifting the burden of proof of fairness to the legislators who drew the lines. Perhaps the strongest support for the use of automated models would be the not inconceivable judicial holding that nonautomated plans whose bases cannot be explained are per se arbitrary and capricious, and thus invalid.

42. For examples, see sources cited supra note 37 . These programs produce plans when given input data such as census population and geographic information.

43. For an example, see Weaver \& Hess, supra note 11, at 301-04.

44. If a politician were allowed to choose between two computer generated plans, then accountability would require full disclosure of the reasons for her choice, which involves problems of discerning subjective motivations. See supra note 32 . Generating a single plan means that the entire range of choices that went into the model is built into the compuier program, available for review by courts or the public. 
working with criteria that are not only extensive, but also potentially conflicting. ${ }^{45}$ Regarding the complexity of the criteria, virtually any issue in redistricting that can be handled manually can be included in an automated model. ${ }^{46}$ The charge regarding the problem of conflicts in criteria is similarly misplaced. If the criteria of fair representation conflict, this problem inheres in the criteria themselves, not in automated redistricting. Conflicting criteria may be resolved by assigning weights to the various criteria, and thus should not preclude automated redistricting. Unlike manual redistricting, ${ }^{47}$ however, in which conflicts might be resolved on a case-by-case basis according to the insights of the line drawer, ${ }^{48}$ automated redistricting requires the plan for the resolution of differences to be prepared in advance. Thus, creating a single redistricting algorithm for a jurisdiction requires designers to build into the model tradeoffs of values, ${ }^{40}$ resulting in some loss of flexibility. ${ }^{50}$ This loss of flexibility, however, might also be viewed as a gain in uniformity and accountability.

A different problem arises from the amount of freedom that designers have in creating the model. Presumably, just as they can manipulate lines to reflect their interests, legislators could attempt to manipulate automated redistricting by selecting weights which generate politically desirable results. In an automated process, however, legislators must discuss the criteria of fair redistricting, and the weights assigned to those criteria, explicitly. Thus, they are to some degree accountable to the voters and the courts in their decisions.

The criteria and weights chosen for the final redistricting program

45. For an explanation of the conflicts in redistricting criteria, see Lijphart, supra note 35, at 147-52.

46. See sources cited supra note 37. As a nonmathematical example, consider the case of a legislator who wants his donor or a family member to be placed in his district. Even this problem could be "patched" into a computer program by a program line that does not allow certain data blocks to be separated.

47. This category includes redistricting with a passive use of computers. See supra text accompanying note 38 .

48. For an example of how line drawers address their concerns on a case-by-case basis, see Fund, supra note 18 , at 35 (with census data available down to city block level, redistricters "can 'decide [they] liked the demographics of people on one side of a street more than on the other and draw the district line down the middle between them'" (quoting Republican National Committee consultant Thomas Hofeller)).

49. For example, the computer might be directed to trade off a certain amount of compactness in order to retain population equality. For more complete example of "values" to be traded, see supra note 35 .

50. Currently, flexibility takes the form of line drawers' ability to resolve conflicts on a case-bycase basis. Sep, e.g., Grofman, supra note 13, at 124 ("[Reapportionment] involves the need to reconcile multiple and conflicting desirable social goals not all of which can simultaneously be achieved .... Because there is no simple algorithm by which some specified amount of one public good can be equated with some specified amount of some other aspect of the public interest, the process of reconciling and trading-off competing public values is an inherently political and appropriately legislative task.").

Loss of nexibility from automating redistricting may occur not only within a given state at a given time when redistricting occurs, but also temporally if no changes to the model are allowed over time after the initial formulation. See infra text accompanying notes 51-52. 
should be made publicly available. With such information, it is likely that the courts can develop standards to regulate the shape of the model. Restrictions on political and racial gerrymandering will also affect what terms can be included in the model. However, the actual weights chosen by legislators, as well as the measures used to define, say, compactness, will likely be purely legislative decisions.

Safeguards can be built into the design process to alleviate some concerns about automation. For example, a choice might be made to develop a single computer model for a state to use every ten years without modification, in order to reduce the risk of public perception of impropriety. ${ }^{\mathbf{}}{ }^{1}$ Goncerns over the loss of flexibility resulting from reusing the same computer model every ten years could be addressed by permitting occasional changes to the model, through the use of periodic, binding plebiscites. This technique allows legislators to campaign for or against changing the model, but gives the final decision to the citizens, rather than to potentially self-interested legislators. ${ }^{52}$

The actual design of the algorithm must also insure maximum fairness, or perception of fairness. Fairness in determining the weights of conflicting values could be protected by maintaining a record of why each term of the model was chosen, ${ }^{53}$ and by limiting the type of data used in tests to either old state data, out-of-state data, or artificial data. ${ }^{54}$ Further, the

51. Allowing legislators to decide on their own to change the model every 10 years could risk their manipulation of the process, or would at least risk producing a public perception of unfairness. See supra note 10.

52. Notice that plebiscites are necessarily one person, one vote. Thus, in a plebiscite, a disenfranchised electoral majority can reassert itself. However, this may come at the expense of a disenfranchised minority. See Eule, Judicial Review of Direct Democracy, 99 YAlE L.J. (forthcoming 1990). Examples of the use of plebiscites in redistricting include California's Proposition 118, on California's June 1990 ballot, proposing that any state redistricting plan must be ratified by voters. See Remap Process No Longer a Narrow Political Concern, L.A. Times, Mar. 11, 1990, at A1, col. 5, A41, col. 4. But cf. Lucas v. Forty-Fourth Gen. Assembly of Colo., 377 U.S. 713, $736-37$ (1964), aff d in relev'ant part, v'Rcated in part, 379 U.S. 693 (1965) (referendum on redistricting plan cannot remedy violation of equal protection standards in case of malapportionment).

53. Developing a complete record explaining the basis for the construction of each portion of the redistricting program would be desirable not only for the courts in the event of redistricting litigation, but also for the public in general. This type of disclosure is typically used to explain the background for technical-political decisionmaking. See, e.g., 5 U.S.C. $\$ \S 552(a)(1)-(a)(3), 556(e), 557(c)-(d)$ (1988) (portions of Administrative Procedure Act requiring records to be available to public, and requiring all information used in administrative decision process to be available to public).

54. One may argue that using artificial data actually prevents model designers from creating the best plan possible because it does not allow them to use the latest census and poll results for their state. However, the goal of this requirement is to create a "veil of ignorance" for line drawers, in order to give their computer program the highest possible presumption of fairness. See J. RawLS, A THEORY OF JUSTICE 12 (1971) (discussing veil of ignorance); Schuck, supra note 13, at 1349-56 (using Rawlsian approach to determine "fairness" goals of political redistricting). The suggestion may even be seen as a permutation of Professor Amar's lottery voting proposal, because it forces legislators to choose district maps from behind a veil of ignorance, ideally based on procedurally fair terms. See Note, supra note 10 , at 1294-95 \& nn.68-74. But see Lowenstein \& Steinberg, supra note 33, at 23-24 (claiming, without empirical support, that "neutral" redistricting processes serve to benefit Republicans).

Artificial data have in fact been used in the past to study problems of representation in political redistricting. See Grofman, supra note 23, at 55-56. 
algorithm could be designed by nonpartisan or bipartisan committees, ${ }^{\mathrm{bS}}$ although this step should not be necessary if automating redistricting makes legislators truly accountable in their decisions.

Even if the procedure used to design the redistricting algorithm is carefully planned to facilitate public scrutiny, computers cannot transform redistricting into a "neutral" process. The resulting plan produced by the model will not be neutral: ${ }^{58}$ It will reflect a particular weighing of conflicting values. As one commentator pointed out, it is difficult to specify what a neutral solution to a gerrymandering pröblem might be, "because there is no objective standard against which any redistricting can be compared." ${ }^{27}$ The advantage of automated redistricting lies in its ability to expose the design process, rather than merely the results, to meaningful scrutiny by the public and the courts.

\section{COMPUTERS AND The Courts}

Although the previous Section of this Note has suggested that automated redistricting can lead to the development and implementation of objective standards in redistricting, it is important to examine how an automated process would accord with standards already set by the Supreme Court. This Section will demonstrate that automated redistricting should be well received by the courts, since providing a computer algorithm which describes the redistricting process will ease the adjudication of gerrymandering disputes. The Supreme Court should be particularly amenable to automated redistricting in view of the difficulties that have attended its gerrymandering decisions. ${ }^{58}$

The Court's decision in Karcher v. Daggett ${ }^{59}$ illustrates its awkward approach to gerrymandering cases. In that case, the Court invalidated a New Jersey congressional districting plan with an average deviation from perfect population equality of $0.1384 \%$, even though this deviation is statistically insignificant when compared with expected errors in the census. ${ }^{80}$ The result makes little sense until one reads Justice Stevens' concurrence, which explains that the New Jersey plan appeared on its face to

55. Cf. supra note 30 and accompanying text (discussing use of bipartisan or nonpartisan redistricting committees).

56. Sex supra note 31.

57. Johnston, Constituency Redistribution in Britain: Recent Issues, in Electoral Laws and Their Political Consequences 278 (1986); cf. Betts, Gernymandering Made Easy in 1990, COMPUTERwORLD, Aug. 28, 1989, at 1, 18 ("there is no such thing as a neutral election map" (citing Kimball W. Brace, President, Election Data Services, Inc.)).

58. Cf. Baker v. Carr, 369 U.S. 186, 226 (1962) (maintaining that redistricting decisions would not "ask the Court to enter upon policy determinations for which judicially manageable standards are lacking").

59. 462 U.S. 725 (1983).

60. Ser 462 U.S. at 770 n.4 (White, J., dissenting); see also Note, supra note 15, at 687-89 (claiming strict, statistically insignificant standards like $0.1384 \%$ example of Karcher are "inappropriate"). 
be gerrymandered, ${ }^{\text {b1 }}$ a factor which the opinion of the Court seems to ignore. A student of the Court can read the decision in Karcher as an awkward attempt to find a way to avoid legitimating an egregious gerrymander. ${ }^{62}$ The Karcher decision, however, cannot provide useful standards for future line drawers if the written opinion does not reflect the true grounds for the decision.

One also sees the Court struggling with gerrymandering in Davis v. Bandemer. ${ }^{63}$ That opinion had a majority as to one section, a plurality for two other sections, two other concurrences as to the judgment, and one concurrence in part and dissent in part. ${ }^{64}$ Overall, the Bandemer decision did not even provide workable guidelines for determining whether a political gerrymander was unconstitutional. ${ }^{65}$

It appears that the Court is having difficulty with redistricting decisions $^{6 B}$ because gerrymandering cases at present fit almost perfectly the mold of the classic "polycentric problem." that

[w] may visualize this kind of situation by thinking of a spider web. A pull on one strand will distribute tensions after a complicated pattern throughout the web as a whole. Doubling the original pull will, in all likelihood, not simply double each of the resulting tensions but will rather create a different complicated pattern of tensions. ${ }^{68}$

To pinpoint a gerrymander, one must examine a complicated set of intertwined facts. The decisions made in this type of analysis will necessarily affect political outcomes, possibly in unexpected ways, and factors conflated in a redistricting result cannot be separated as they can be when looking at the terms included in a computer model.

Fuller described three alternatives which might arise when a court attempts to address polycentric problems:

First, the adjudicative solution may fail. Unexpected repercussions make the decision unworkable; it is ignored, withdrawn, or modified, sometimes repeatedly. Second, the purported arbiter ignores judicial proprieties-he 'tries out' various solutions in posthearing confer-

61. See 462 U.S. at 744-65 (Stevens, J., concurring).

62. Cf. A. BICKEL, supra note 28 , at 197 (expressing concern that judicial intervention will legitimate gerrymandering).

63. 478 U.S. 109 (1986).

64. See id. at 112 .

65. See id. at 162 (Powell, J., concurring in part and dissenting in part); see also Note, The Lack of Judicial Direction in Political Gerrymandering: An Invitation to Chaos Following the 1990 Centsus, 40 HaStings L.J. 1067, 1068-69 (1989) (claiming Bandemer fails to "provide sufficient guidance to state legislators for the [post-1990] reapportionment").

66. For an extensive discussion of the problems in the Court's adjudication of gerrymandering claims, see Note, supra note 65 , at 1070-85.

67. See Fuller, The Forms and Limits of Adjudication, 92 HARv. L. Rev. 353, 394-404 (1978).

68. Id. at 395 . 
ences, consults parties not represented at the hearings, guesses at facts not proved and not properly matters for anything like judicial notice. Third, instead of accommodating his procedures to the nature of the problem he confronts, he may reformulate the problem so as to make it amenable to solution through adjudicative procedures. ${ }^{68}$

One can easily see the threat of the first type of reaction to some of the Supreme Court's decisions on redistricting. For example, unless the Bandemer decision is supplemented by workable criteria, it may, as Justice O'Connor fears, "prove unmanageable and arbitrary."70

In contrast to the previous results-oriented approaches to redistricting adjudication, a computerized redistricting process can serve to make this polycentric problem amenable to court review. An automated process provides a court with a description of how and why district boundaries were selected, at a level of detail that even full disclosure of intent under the present system could never provide. Given a computer program and the plan produced by it, a court could rule on straightforward questions, such as whether it is allowable for those drawing lines to use political or racial data in formulating a plan. ${ }^{\mathbf{7 1}}$ Judges could easily examine the redistricting algorithm to observe whether the line drawers took into consideration criteria such as compactness or adherence to political boundaries. ${ }^{72}$ The availability of this type of judicially reviewable information could lead to what Justice Powell had in mind in his Bandemer concurrence, when he urged the development of judicially manageable standards to determine "whether the boundaries of the voting districts have been distorted deliberately and arbitrarily to achieve illegitimate ends."73

Additionally, courts should prefer analyzing a redistricting procedure written into computer models to requiring proportional representation, which is the most common alternative given for managing the polycentric

69. Il. at 401 .

70. 478 U.S. at 155 (O'Connor, J., concurring).

71. Se' supro note 41. This amenability to judicial review does not answer the question of what the Court might or should do when faced with an apparently straightforward use of harmless data which is actually used as a proxy for covering up intentional, unconstitutional gerrymandering. It is possible that such uses may be beyond judicial control; one might at most see discriminatory effects used as evidence of intent, a method that the Court tends to use when assessing the actions of state and local legislatures. Ser infra Section IV. Once a specific algorithm is officially adopted as a state's rcdistricting method, however, the influence of the original designer will decrease over time as demographics change, since the model will produce results that its creator could probably not have anticipated. This time effect should reduce the incentive to create elaborate, subtle gerrymanders. In addition, the fact that a model will be used more than once over time might discourage judges from actively voiding computer terms which, though they may act as proxies in one year, might be independently justifiable. $C f$. Davis v. Bandemer, 478 U.S. at 139 (plurality opinion) ("mere lack of proportionate results in one election cannot suffice [to show unconstitutional discrimination]").

72. The opportunity afforded judges by computer models to examine the terms used in redistricting can be viewed as a method which gives substance to the proposal that "the Court must focus more on the objective standards of political gerrymandering, such as the . . compactness concept advocated by Justice Powell." Comment, supra note 7 , at 233.

73. 478 U.S. at 165 (Powell, J., concurring in part and dissenting in part) (construing Justice Fortas' concurrence in Kirkpatrick v. Preisler, 394 U.S. 526, 538 (1969)). 
problem of redistricting. ${ }^{74}$ While testing for proportional representation would appear to be one means of providing a judicially manageable standard in gerrymandering cases, this type of representation has been strongly opposed in the United States. For example, the Voting Rights $\mathrm{Act}^{75}$ and the cases under it suggest that neither Congress nor the courts view proportional representation as a fundamental right. ${ }^{76}$ Justice O'Connor commented in her Bandemer opinion that requiring proportionality "would be calamitous for the federal courts, for the States, and for our two-party system."'77 In contrast, judges do not seem to be opposed to looking at the process used to redistrict; Justice Powell has declared that in gerrymandering cases, "a court should look first to the legislative process by which the challenged plan was adopted."

Once one accepts that the use of computer models in redistricting might be desirable from a judicial standpoint, a reexamination of the decision in Karcher leads to a striking conclusion. The Court in Karcher, after striking down the New Jersey plan for failure to meet equal population standards, held that

[a]ny number of consistently applied legislative policies might justify some variance [from perfect population equality], including, for instance, making districts compact, respecting municipal boundaries, preserving the cores of prior districts, and avoiding contests between incumbent Representatives. ${ }^{79}$

This suggests that the Court has been looking for the exact kind of consistency and accountability in redistricting that a computer model would supply. An algorithm which focuses on a few redistricting criteria such as compactness and contiguity, and explicitly contains an explanation of the tradeoffs and procedures used in redistricting, could meet the requirements of the Court, even if it does not attain perfect equality across districts.

74. See, e.g., Schuck, supra note 13, at 1361-77 (describing "Siren's song of Proportional Representation"); Comment, supra note 7, at 187 (describing Bandemer as "latest step in [the Court's] progression toward proportional representation").

75. 42 U.S.C. $\$ 1973$ (b) (1982) (providing that "nothing in this section establishes a right to have members of a protected class elected in numbers equal to their proportion in the population").

76. See, e.g., Thornburg v. Gingles, 478 U.S. 30, 46 (1986) (acknowledging that "conjunction of an allegedly dilutive electoral mechanism and the lack of proportional representation alone does not establish a violation [of the Voting Rights Act]').

77. 478 U.S. at 155 (O'Connor, J., concurring).

78. Id. at 175 (Powell, J., concurring in part and dissenting in part). Justice Powell probably did not intend to require the legislative process used in redistricting to withstand scrutiny as strict as that which a redistricting algorithm would survive, but this fact only improves the chances that an automated model would meet the Court's standards.

79. 462 U.S. at 740 (emphasis added). 


\section{Automated Gerrymandering and the Intent/Effect DICHOTOMY}

In discussing how automated redistricting could meet the standards of voters and the courts, this Note has not addressed the fact that in any redistricting situation, the use of an automatic model might produce results that disproportionately favor or disfavor some group. ${ }^{30}$ According to Section Two of the Voting Rights Act, racial gerrymandering is suspect in its effects. ${ }^{81}$ Any computer algorithm for redistricting must take this fact into account. ${ }^{82}$ However, an analysis of case law suggests that this focus on redistricting effects should be limited to the racial example. If an automated process is not designed to discriminate against a party in any state, the focus of litigation should not be the resulting redistricting plan, but rather whether the reviewable inputs to the model are defensible. ${ }^{83}$

In determining whether the effects of an automated plan should be a consideration in the nonracial redistricting case, it is important to note that it has been difficult for courts to examine redistricting plans for unconstitutionally discriminatory effects. The Court in Thornburg v. Gingles struggles to follow the Voting Rights Act's requirements without resorting to a standard of proportional representation. ${ }^{84}$ Although unconstitutionality of effect is a difficult standard to apply, Justice O'Connor explains that the "nexus between individual rights and group interests, and the greater warrant the Equal Protection Clause gives the Federal courts to intervene for protection against racial discrimination, suffice to render racial gerrymandering claims justiciable." ${ }^{\text {"85 }}$ The Voting Rights Act

80. Consider, for example, a scenario in which politicians working on a redistricting model included factors of compactness, contiguity, and minority representation in their program, but did not consider political party representation, and the resulting plan happened to pack all voters of one party into a disproportionately small number of districts. Cf. Dixon, Fair Criteria and Procedures for Establishing Legislatite Districts, in REPRESENTATION AND REDISTRICTING Issues, supra note 23, at 7, 18-19 (then-Professor Robert Bork, as special master in redistricting case, inadvertently produced plan heavily favoring Democratic party despite use of essentially census data alone); R. BoRk, The Tempting of america: The Political Seduction of the Law 88-89 (1990) (same).

81. 42 U.S.C. $\$ 1973$ (1982). This provision essentially overturned the Court's decision in City of Mobile v. Bolden, 446 U.S. 55 (1979), which had held that unconstitutional discrimination requires a showing of intent, id. at 55, suggesting that the new statutory rule cannot be treated lightly by the Court.

82. For example, to withstand Court scrutiny, the computer model might need to use data that has some units aggregated in advance, in order to guarantee adequate minority representation. $C f$. United Jewish Org. v. Carey, 430 U.S. 144 (1976) (allowing planners to try to attain 65\% nonwhite population in district). In an automated redistricting model, the prior aggregation of voters by race will be reviewable by the courts. The courts will therefore be able to develop meaningful, objective standards regarding acceptable aggregation in the redistricting process.

83. Consider, for example, the case in which plans drawn with townships as the smallest indivisible units tend to favor Party A whereas plans splitting up townships tend to favor Party B. In this example, it should be the choice of data used, rather than the results, which must be justified. If, for example, the State's model, using census units much smaller than townships, appears consistently to favor Party B, then it can be argued that it is the township boundaries that are unfair, rather than the redistricting scheme.

84. See Thornburg v. Gingles, 478 U.S. 30 (1986).

85. Davis v. Bandemer, 478 U.S. 109, 151 (1986) (O'Connor, J., concurring). 
finds that protection against discriminatory effect is necessary to aid in the effort to avoid retrogression of minority representation. O'Connor, however, states that an effects test should not be applied to political gerrymandering. ${ }^{86}$

Because political gerrymandering may be suspect only in its intent, an automated process which could meet the Court's standards might be acceptable even if the political results occasionally appear skewed. For example, Justice Powell in Bandemer states that gerrymandering is "the deliberate and arbitrary distortion of district boundaries and populations for partisan or personal political purposes." ${ }^{\text {" }}$ This implies that the Court might use a process-oriented approach to determine unconstitutional political gerrymandering; if the automatic model is not designed to discriminate, ${ }^{88}$ then the Court might uphold its results regardless of their political effects. ${ }^{89}$ At most, effects might be used as evidence of intent, a method that the Court sometimes uses to examine the constitutionality of actions of state and local legislatures. ${ }^{90}$

Automated redistricting is suited for separating intent from effect in redistricting in a way previously impossible, since it can make available records of exactly why lines were drawn where. ${ }^{91}$ The Supreme Court, too, in explaining that "a finding of unconstitutionality [in political gerrymandering] must be supported by evidence of continued frustration of the will of a majority of the voters, ${ }^{102}$ implies that it might be willing to accept the use of an automated model even if the model's results occasionally seem skewed. There is no reason to expect that a computer model should consistently or unfairly favor one party over another..$^{93}$

The difficulty one faces in trying to determine whether a plan is unconstitutional based on its results might suggest that the appropriate test of a gerrymander should in fact focus on the process used to redistrict. Perhaps observers have had difficulty objectively defining a gerrymander exactly because their focus on results has been misguided. Maybe, as Powell implies, a "gerrymander" must be by definition deliberate. The use of automated computer models, then, by facilitating judicial review of the redistricting process, might be one of the only ways of promoting fairness in redistricting.

86. Id. at 161 .

87. Id. at 164 (Powell, J., concurring in part and dissenting in part) (citing Kirkpatrick v. Preisler, 394 U.S. 526, 538 (1969)) (emphasis added).

88. But see supra note 71 (describing potential danger of discrimination by proxy).

89. In contrast, the court might find that the existence of a political packing term in the algorithm is either per se illegal, or else that it shifts the burden of proof of fair redistricting to the proponents of a challenged plan. See supra note 41.

90. See G. Gunther, Constitutional Law 277 (11th ed. 1985).

91. See supra Section II.

92. Davis v. Bandemer, 478 U.S. 109, 133 (1986).

93. But of. Lowenstein \& Steinberg, supra note 33, at 23-24 (claiming "neutral" redistricting processes serve to benefit Republicans). 


\section{Public Acceptance of Fixed Mathematical and Process- Oriented Standards in Political Problems}

Despite the theoretical benefits of automated redistricting, individuals may still hesitate to accept the creation of a single computer program that affects political outcomes by taking political values, such as tradeoffs between compactness and equality of population, out of the hands of people and fixing them over time. However, a look at some major processes related to voting, including the reapportionment problem, the "one person, one vote" rule, and the "first past the post" system of single member districting, suggests that people have instead widely accepted several fixed mathematical techniques which have had major political consequences.

The reapportionment problem provides perhaps the best example of the use and acceptance of a fixed mathematical technique in the political arena. ${ }^{94}$ The task of reapportionment is to assign congressional seats to states. The necessity of assigning seats based on the census was one of the first items covered in the Constitution, ${ }^{95}$ yet no method was mandated by the Framers. Many different mathematical reapportionment techniques, each of which would lead to different political outcomes, are possible. ${ }^{98}$ Some countries do not even use a mathematical technique to reapportion and instead rely upon negotiation. ${ }^{97}$ Yet this country has accepted the choice of a single method to allocate seats given census data, without human intervention.

Both reapportionment and redistricting affect political outcomes, and both require tradeoffs of conflicting values. The choice of reapportionment method may be used, for example, to discriminate consistently against larger states, as the current method presently does. ${ }^{98}$ Additionally, the results of reapportionment, like those of redistricting, can be quite significant. For example, just as redistricting can affect the political makeup of Congress, ${ }^{9 \theta}$ reapportionment can affect presidential elections. ${ }^{100}$ And like redistricting, reapportionment can affect the over- or under-representation of rural or urban voters in legislatures. ${ }^{101}$ "The fact is that political real-

94. For a comparison of reapportionment and redistricting from a political science perspective rather than a process-oriented perspective, see Edwards, Theoretical and Comparatite Aspects of Reapporthonment and Redistricting: With Reference to Baker v. Carr, 15 VAND. L. REv. 1265 (1962).

95. U.S. CoNST. art. I, $\$ 2, \mathrm{cl} .3$ (providing for decennial census and congressional apportionment based on results).

96. For example, Webster's method, Hamilton's method, Jefferson's method, and the "method of equal proportions." See generally M. Balinski \& H. Young, FaIR RePresentation: MeEting THE IDEAL OF ONE MAN, ONE Vote (1982).

97. For example, France and England. $I d$. at 3.

98. Sep id. at 4.

99. Sep Rosenbaum, supra note 24 , at E1, col. 1 .

100. See, e.g., M. Balinski \& H. Young, supra note 96, at 2-3 (1982) (malapportionment of 1870 's led to electoral college which made Rutherford B. Hayes President although opponent won 51.6 percent of vote).

101. Compare id. at 2-3 (one danger of reapportionment "is a significant shift of seats from small 
ists from Alexander Hamilton in 1792 to Arthur Vandenberg in 1941 have engaged in bitter conflicts over methods of apportionment whose effects were to transfer as few as one seat."102 Reapportionment is not a trivial political problem; indeed, redistricting and reapportionment are closely related. If any state loses or gains even one congressional seat due to a post-census reapportionment, the boundaries of every single district in the state may change. ${ }^{103}$

Given the similar magnitude of the political effects of reapportionment and redistricting solutions, the widespread acceptance of the use of a mathematical process over a technique of negotiation in reapportionment suggests that the development of a computer program to solve the redistricting problem may also be well received by voters. It is likely that reapportionment is accepted as a mathematical process because it has already been implemented as such; many of the alleged representational or political differences between reapportionment and redistricting might appear either artificial or less significant if a redistricting algorithm were actually implemented in one or more jurisdictions.

A second example of a widely accepted mathematical standard used in politics is the "one person, one vote" rule first enunciated in the Reynolds decision. ${ }^{104}$ The Constitution requires no such standard of representation, and calls for the creation of a Senate which blatantly violates the one person, one vote rule. ${ }^{105}$ Additionally, Professor Ely argues that the only obvious benefit of the rule is its simplicity, and that the Court might have constitutionally allowed rural districts to be given disproportionately high representation. ${ }^{108}$ Yet the one person, one vote standard proved "so attractive in its manifest simplicity and in its congruence with commonsense notions of fair representation" ${ }^{107}$ that it has apparently received the widespread support of the public. One wonders if the use of computer models in redistricting might gain similar acceptance by the voters.

The "first past the post" (FPP) system of voting ${ }^{108}$ used in American single member districting also represents a fixed standard accepted in the political arena even though it is imperfect, it is not the only process possible, and its use has important political repercussions. For example, FPP

rural states to large industrial states-or the reverse-depending upon the method used") writh A. BICKEL, supra note 28 , at 189-90 (impetus for redistricting cases originally involved disparity in representation of urban and rural voters).

102. M. Balinski \& H. YounG, supra note 96, at 3 (emphasis added).

103. In fact, the loss of a congressional seat in a state should change every district in the state according to the current population equality standards required by the Supreme Court, except in the rare case where every district has naturally lost the same number of people.

104. Reynolds v. Sims, 377 U.S. 533 (1964).

105. See U.S. ConsT. art. I, $\$ 3$ (providing that "Senate of the United States shall be composed of two Senators from each State. . a and each Senator shall have one Vote").

106. J. Ely, Democracy and Distrust 121 (1980).

107. Schuck, supra note 13 , at 1381 .

108. See definition supra note 23 . 
virtually guarantees a disparity between votes and seats in districts, ${ }^{109}$ yet proportional representation as an alternative is opposed, ${ }^{110}$ and multimember districting and at-large elections are often challenged as discriminatory, ${ }^{111}$ while FPP is accepted as the norm.

These examples of widely accepted, fixed approaches to political and specifically voting-related problems suggest promise for the use of an automatic method to redistrict states. ${ }^{112}$ While politicians might initially resist the development of a computer program to redraw district boundaries, ${ }^{113}$ and political scientists might try to distinguish redistricting from other types of fixed "mathematical" processes in voting, ${ }^{114}$ a model once selected may receive widespread popular support.

\section{Conclusion}

Supreme Court redistricting decisions, like Baker v. Carr ${ }^{115}$ and Reynolds $v$. Sims, ${ }^{116}$ have radically changed approaches to redistricting. ${ }^{112}$ Therefore, now that the Davis v. Bandemer ${ }^{118}$ decision has found political gerrymandering to be justiciable for the first time, it is likely that the redistricting process will change again in the future. ${ }^{119}$ Anticipating this potential for change after the 1990 census, individuals should realize that it is time to start rethinking the possibility of designing and implementing an automated computer model for political redistricting.

This Note has not argued that developing a new computer model for redistricting would be easy. Creating a state-of-the-art redistricting model

109. Sere supra note 23.

110. Sie supra notes 74-77 and accompanying text.

111. See, e.g., Rogers v. Ladge, 458 U.S. 613 (1982) (plaintiffs claim at-large election scheme dilutes Black voting power); City of Mobile v. Bolden, 446 U.S. 55 (1980) (plaintiffs claim Mobile, Alabama's practice of at-large elections for City Commissioners dilutes Black voting power); White v. Regester, 412 U.S. 755 (1973) (plaintiffs claim multi-member districts are invidiously discriminatory against racial or ethnic groups).

112. Other widely accepted "mathematical" standards accepted in the political arena despite their problems include the draft and jury lotteries. See Note, supra note 10 , at $1289 \& \mathrm{nn} .36-38$. This high level of acceptance has occurred even though, as in the previous examples, the process has been far from perfect. Sie Gleick, The Quest for True Randomness Finally Appears Successful, N.Y. Times, Apr. 19, 1988, at C1, col. 3, C8, col. 4 ("[Only after the draft lottery] did statisticians establish that the procedure had been far from random; people born toward the end of the year had a far greater chance of being drafted than people born in the early months. In general, the problem of mixing or stirring or shuffling things to insure randomness is more complicated than most experts assume.").

113. Opposition may arise because such a technique would both take away power from legislators and force legislators to be accountable in their choices of redistricting criteria.

114. S't', e.g., Dixon, supra note 31, at 10-11 ("Legislative elections and the party system which organizes them are critical parts of the American process of political representation. We expect far more from the election system than mere filling of legislative seats.").

115. 369 U.S. 186 (1962).

116. 377 U.S. 533 (1964)

117. Prior to these decisions, "very few State Legislatures were following a really good faith effort at redistricting themselves following each census." Council. OF STATE GovernMents, supra note 17, at 10. Since Baker and Reynolds, states are held to very high redistricting standards. See cases cited supra note 3 .

118. 478 U.S. 109 (1986)

119. Ser supro notes 7-8 and accompanying text. 
will require efforts from politicians and political scientists as well as from computer scientists. Battles over values to be embedded in the model may in fact resemble previous lengthy battles over final redistricting plans. Further, this Note has not attempted to suggest which values might be acceptable in such a model. This Note has explained, though, that some unique, process-oriented benefits would result from making political redistricting an automated process.

Ultimately, this Note challenges readers to see political redistricting as a case in which "the existence of a clear rule or an unambiguously functioning institution may . . . be more important than the content of the rule or design of the institution." ${ }^{200}$ The clear rule or institution here is the computer program which would apply the redistricting algorithm for a jurisdiction every ten years without pause. The benefit of having a consistent method of determining district lines quickly, without court challenges, makes automated redistricting an important goal for the near future.

Is automated redistricting a misguided attempt to "take the politics out of politics?" Well, in the final analysis, what is politics? When the founders of this country designed the political institutions standing today, they worked with the understanding that "[i]f men were angels, no government would be necessary."121 Accordingly, they created a government as a system of checks and safeguards, designed to protect our safety and wellbeing. "Politics" must take place within the constraints of this governmental structure. With today's technological power, we have the ability to raise politics to a level never previously imaginable, since automated redistricting can be used to create a new framework within which legitimate debate can occur. Perhaps, then, automated redistricting should really be seen as an effort to "put good politics back into politics."

120. Simon, The Authority of the Framers of the Constitution: Can Originalist Interpretation Be Justified?, 73 CALIF. L. REv. 1482, 1525 (1985) (discussing "rule-of-law virtues").

121. The Federalist No. 51, at 322 (J. Madison) (C. Rossiter ed. 1961). 